\title{
Origin of methane in high-arsenic groundwater of Taiwan - Evidence from stable isotope analyses and radiocarbon dating
}

\author{
Tsung-Kwei Liu ${ }^{\text {a,* }}$, Kuan-Yu Chen ${ }^{\text {a,b }}$, Tsanyao Frank Yang a , Yue-Gau Chen ${ }^{\text {a }}$, Wen-Fu Chen ${ }^{c}$, Su-Chen Kang ${ }^{\text {a }}$ \\ Chih-Ping Lee ${ }^{a}$
}

${ }^{a}$ Department of Geosciences, National Taiwan University, Taipei, Taiwan, ROC

${ }^{\mathrm{b}}$ Energy and Environment Research Laboratories, Industrial Technology Research Institute, Hsinchu, Taiwan, ROC

${ }^{\mathrm{c}}$ Institute of Hot Spring Industry, Chia Nan University of Pharmacy and Science, Tainan County, Taiwan, ROC

\section{A R T I C L E I N F O}

\section{Article history:}

Received 29 August 2008

Received in revised form 12 June 2009

Accepted 25 June 2009

\section{Keywords:}

Methane $\left(\mathrm{CH}_{4}\right)$

Dissolved inorganic carbon (DIC)

High-arsenic groundwater

Taiwan

Stable isotopes

Radiocarbon dating

\begin{abstract}
A B S T R A C T
Groundwaters in the confined aquifers of the Chianan and Ilan coastal plains of Taiwan are rich in dissolved methane $\left(\mathrm{CH}_{4}\right)$. Serious endemic "blackfoot disease", which occurred in the Chianan plain, especially during AD1950-1970, has been demonstrated to have arisen from drinking highly reducing groundwater with abnormal arsenic and humic substance levels. In order to explore the origin of $\mathrm{CH}_{4}$ and its hydrological implications, stable carbon isotope ratios $\left(\delta^{13} \mathrm{C}\right)$ and radiocarbon $\left({ }^{14} \mathrm{C}\right)$ ages of exsolved $\mathrm{CH}_{4}$, dissolved inorganic carbon (DIC), and sedimentary biogenic sediments from a total of 34 newly completed water wells at 16 sites were determined. The main results obtained are as follows: (1) The $\delta^{13} \mathrm{C}_{\mathrm{CH}_{4}}(-65 \%$ to $-75 \%$ ) values indicate that, except for one thermogenic sample $\left(\delta^{13} \mathrm{C}_{\mathrm{CH}_{4}}=38.2 \%\right.$ ) from the Ilan plain, all $\mathrm{CH}_{4}$ samples analyzed were produced via microbially mediated $\mathrm{CO}_{2}$ reduction. Many $\delta^{13} \mathrm{C}_{\mathrm{DIC}}$ values are considerably greater than $-10 \%$ and even up to $\sim 10 \%$ due to Rayleigh enrichment during $\mathrm{CO}_{2}$ reduction. (2) Almost all the ${ }^{14} \mathrm{C}$ ages of $\mathrm{CH}_{4}$ samples from the shallow aquifer (I) ( $<60 \mathrm{~m}$ depth) are greater than the ${ }^{14} \mathrm{C}$ ages of coexisting DIC and sediments, suggesting the presence of $\mathrm{CH}_{4}$ from underlying aquifers. (3) The ${ }^{14} \mathrm{C}$ ages of coexisting $\mathrm{CH}_{4}$, DIC and sediments from aquifer (II) of the Chianan plain are essentially equal, reflecting in-situ generation of $\mathrm{CH}_{4}$ and DIC from decomposition of sedimentary organic matter and sluggishness of the groundwater flow. On the other hand, both $\mathrm{CH}_{4}$ and DIC from each individual well of the relatively deep aquifers (III) and (IV) in the Chianan plain are remarkably younger than the deposition of their coexisting sediments, indicating that current groundwaters entered these two aquifers much later than the deposition of aquifer sediments. (4) Each $\mathrm{CH}_{4}$ sample collected from the Ilan plain is older than coexisting DIC, which in turn is distinctly older than the deposition of respective aquifer sediments, demonstrating the presence of much older $\mathrm{CO}_{2}$ and $\mathrm{CH}_{4}$ from underlying strata.
\end{abstract}

(c) 2009 Elsevier Ltd. All rights reserved.

\section{Introduction}

Considerable amounts of dissolved methane $\left(\mathrm{CH}_{4}\right)$ are often present in groundwaters pumped from wells tapping confined aquifers in the Chianan and Ilan alluvial coastal plains of SW and NE Taiwan, respectively (Fig. 1). These groundwaters are also characterized by high concentrations of dissolved humic substances and arsenic (Chen and Liu, 2007), both of which were considered to be responsible for endemic "blackfoot disease" through drinking of groundwater (Tseng et al., 1961; Lu, 1990). It has long been recognized that occurrence of $\mathrm{CH}_{4}$ generally implies a considerably reducing state in the geochemical environment (Stumm and Mor-

\footnotetext{
* Corresponding author. Tel./fax: +8862 23657380 .

E-mail address: liutk@ntu.edu.tw (T.-K. Liu).
}

gan, 1996). In addition, strongly reducing waters tend to be contaminated by heavy metals and natural discharges are likely to be minimal (Smedley and Kinniburgh, 2002; Gooddy and Darling, 2005). Previous studies of dissolved gas from the six water wells drilled by the Chinese Petroleum Corporation in the Chianan plain focused mainly on the potential for profitable production (Hsu, 1984), and the composition of the gas was shown to contain more than $90 \% \mathrm{CH}_{4}$, up to $6 \% \mathrm{CO}_{2}$, and a few percent $\mathrm{N}_{2}$. However, the origins and source of $\mathrm{CH}_{4}$ in these aquifers have not been well studied.

Dissolved methane in groundwater can be formed via bacterial reduction, or from thermogenic decomposition of organic matter at relatively high temperatures. Furthermore, the former type can proceed through either reduction of dissolved forms of $\mathrm{CO}_{2}$ (i.e., $\mathrm{CO}_{2}+4 \mathrm{H}_{2} \rightarrow \mathrm{CH}_{4}+2 \mathrm{H}_{2} \mathrm{O}$ ) or acetate fermentation (i.e., $\mathrm{CH}_{3} \mathrm{COO}^{-}+$ $\mathrm{H}_{2} \mathrm{O} \rightarrow \mathrm{CH}_{4}+\mathrm{HCO}_{3}^{-}$) (Schoell, 1980, 1988; Oremland et al., 1982). 


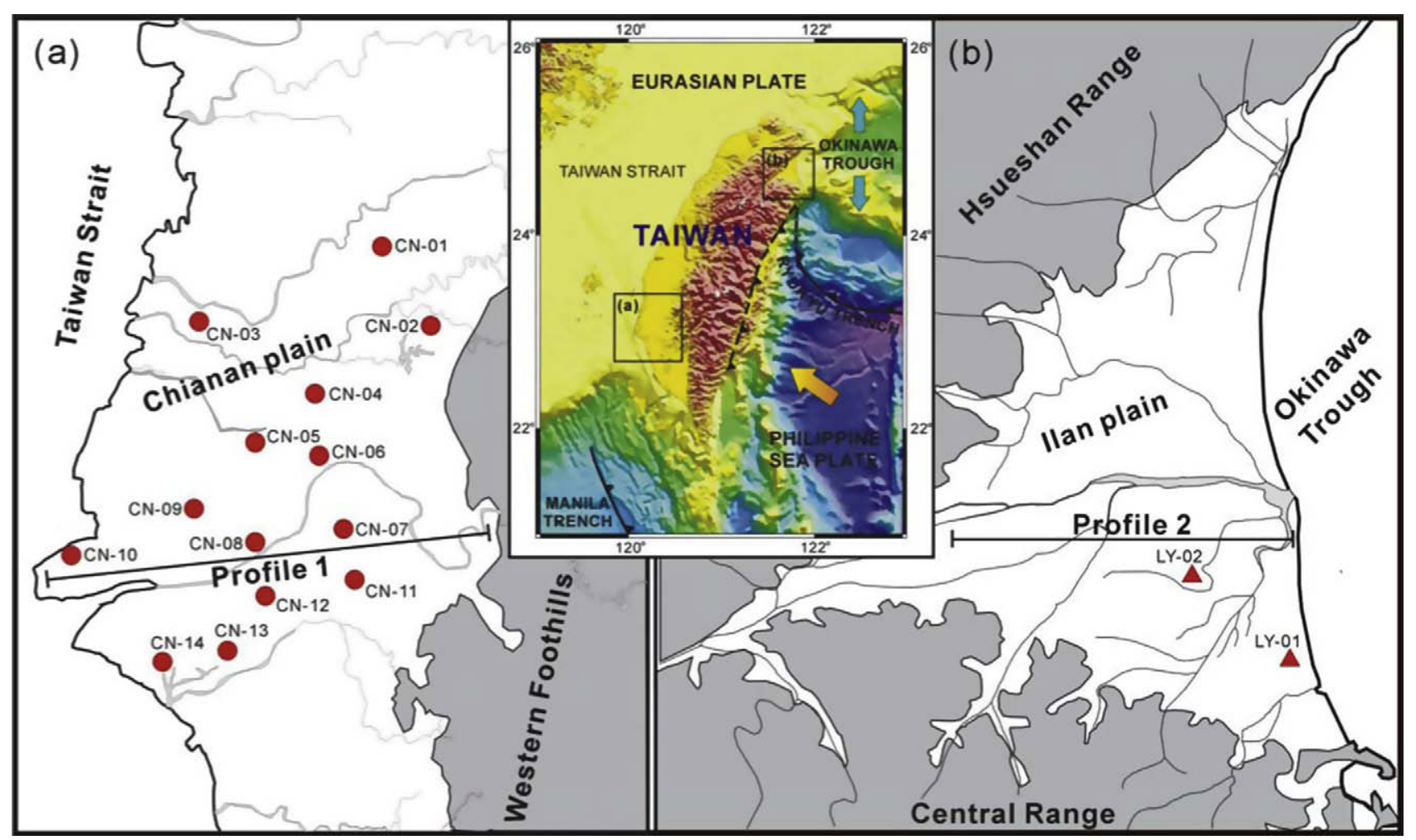

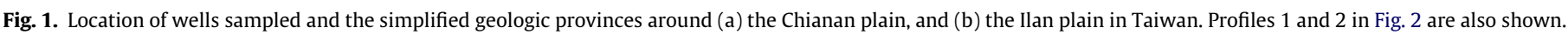

The best diagnostic tool for identifying the origin of $\mathrm{CH}_{4}$ in the groundwater environment appears to be the ${ }^{13} \mathrm{C}$ and ${ }^{2} \mathrm{H}$ fractionation between coexisting $\mathrm{CH}_{4}$ and $\mathrm{CO}_{2}$ (Oremland, 1988; Coleman et al., 1988; Whiticar et al., 1986; Whiticar, 1999; Lansdown et al., 1992; Aravena et al., 1995, 2003). It has long been recognized that the stable carbon isotope ratios $\left(\delta^{13} \mathrm{C}\right)$ of thermogenic methane range from $-30 \%$ to $-50 \%$, and are mostly greater than $-45 \%$ o (Barker and Fritz, 1981; Tyler, 1991). By contrast, $\delta^{13} \mathrm{C}$ values for microbial $\mathrm{CH}_{4}$ are less than $-50 \%$ and mostly fall in the range $-50 \%$ o to $-65 \%$ for acetate fermentation pathway and $-65 \%$ o to $-90 \%$ for $\mathrm{CO}_{2}$ reduction pathway. In addition to the problem of the origin of $\mathrm{CH}_{4}$, it is also interesting to know whether $\mathrm{CH}_{4}$ was formed in-situ. The purpose of this study is to verify the origin and source of $\mathrm{CH}_{4}$ associated with groundwater in the Chianan and Ilan plains by using stable carbon isotopes and radiocarbon dating of $\mathrm{CH}_{4}$, DIC and shell (or plant) sediments collected from 34 recently drilled groundwater-monitoring wells. A $\delta^{2} \mathrm{H}$ value was measured for a $\mathrm{CH}_{4}$ sample to further support its origin identified by $\delta^{13} \mathrm{C}$ criterion.

\section{Hydrogeological setting}

\subsection{Chianan plain}

The Chianan plain is a part of the coastal plain of southwestern Taiwan, covering about $1100 \mathrm{~km}^{2}$ with a N-S length of approximately $40 \mathrm{~km}$ and an average E-W width of $30 \mathrm{~km}$. The ground surface slopes seaward with a very low gradient. It is bounded on the east by the western edge of the Western Foothills, which is mostly composed of siltstone and fine-grained sandstone of the late Tertiary epoch and provides the source rocks for the Chianan plain (Ho, 1975). Accordingly, the upper-most $\sim 300 \mathrm{~m}$ of which is mostly silt and clay, intercalated with thin lenticular fine-sand layers (Fig. 2a; Chen and Liu, 2007); these sediments were deposited in mixed sedimentary environments, including lagoon, estuarine, shallow marine, and fluvial plains during late Pleistocene and Holocene. The average rate of sediment accumulation during Holocene reached a high value of $\sim 1 \mathrm{~cm} / \mathrm{yr}$ in the coastal areas as determined by radiocarbon dating (Liu et al., 1997).

Based on grain-size of sediments, the upper $\sim 300$-m thick strata at each well locality are generally divided into four aquifers: I, II, III and IV from top to bottom. Unconfined aquifers are limited to the upper few meters of the plain, even at the eastern parts adjoining the hills. Hydrogeological characteristics are consistent with the very low permeability shown in pumping tests and the occurrence of saline water in the aquifers deposited in a marine environment. Chen and Liu (2007) interpreted the high chlorinity for some wells in aquifer (I) as being due to strong evaporation in the coastal zone.

\subsection{Ilan plain}

The Ilan plain is located in the western tip of the rifting back-arc basin of the Okinawa Trough. This plain is triangular in shape and bounded by low-grade metamorphic rocks of the Hsueshan Range and medium-high grade metamorphic rocks of the Central Range to the northwest and the south, respectively. The upper $120-\mathrm{m}$ thick layer was deposited during Holocene and its average sediment accumulation rate is similar to the Chianan plain, also reaching a high of $\sim 1 \mathrm{~cm} / \mathrm{yr}$. Grain-sizes of sediments in most parts of the plain decrease distinctly from gravel in the proximal part to silt/clay in the coastal area. A relatively shallow (<20 m depth) and thick $(\sim 10 \mathrm{~m})$ clayey layer acts as the upper-most aquitard overlying the confined aquifers in the middle and distal parts. The $\mathrm{CH}_{4}$ samples analyzed were taken from the southern margin of the plain, where the whole pile of strata drilled through for this study is basically composed of dark-gray clay intercalated with thin layers of silt and fine-grained sand (Fig. 2b). 


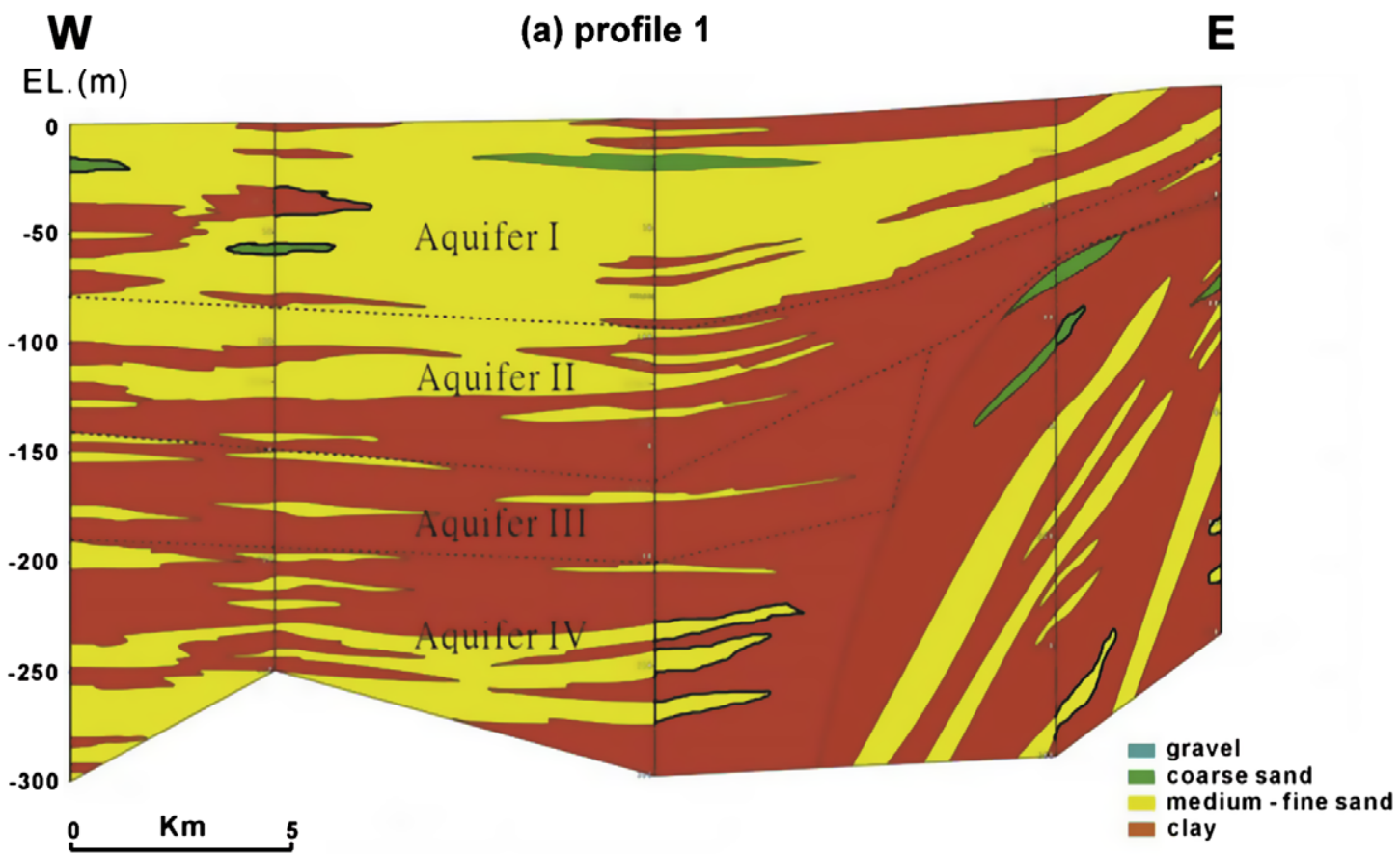

W

(b) profile 2

$\mathbf{E}$

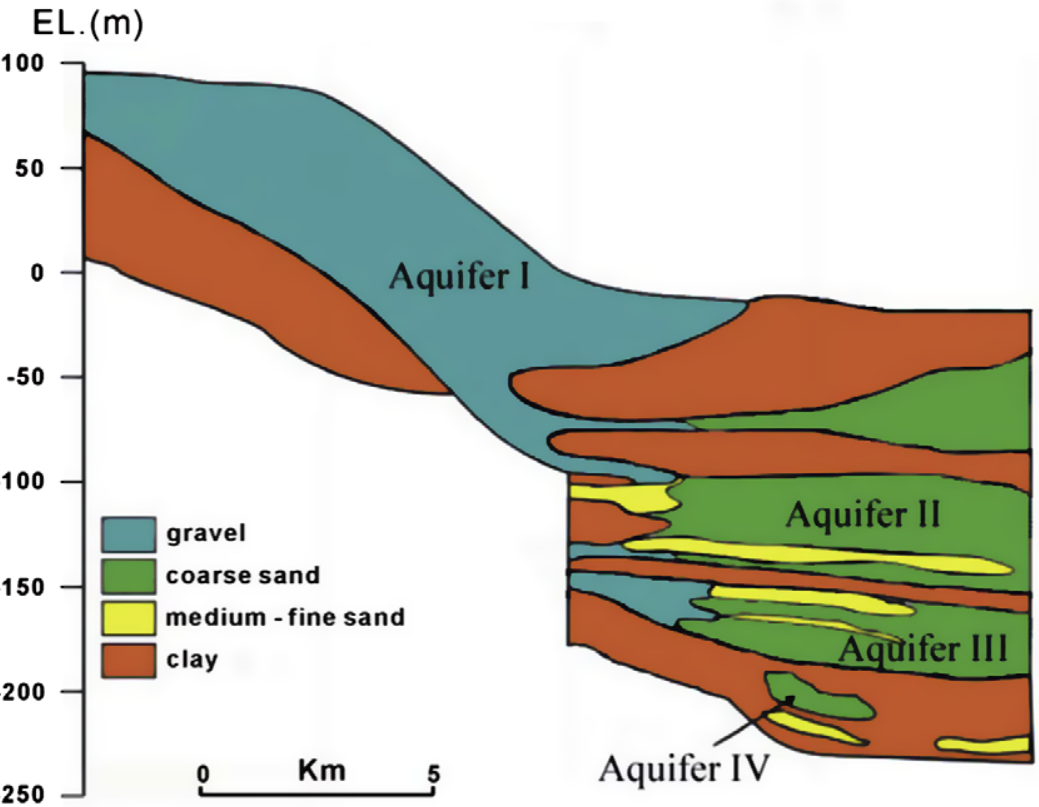

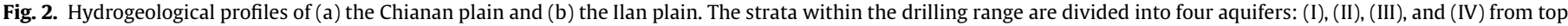
to bottom. Location of profile lines is shown in Fig. 1.

\section{Samples and analytical methods}

During the establishment of the groundwater-monitoring network of Taiwan, continuous sediment cores of up to $250 \mathrm{~m}$ or more in length were taken and up to four wells tapping individual aquifers were drilled at each monitoring site. Most of the water samples were collected from the same wells as those used by Chen and Liu (2007) for arsenic study. The water samples were ensured to be fresh and representative by pumping each well long enough to replace the free-standing water in the casing before taking samples. About 501 of each water sample was collected from these wells for precipitation of dissolved inorganic carbon (DIC) for ${ }^{14} \mathrm{C}$ dating using the procedures described previously by Hackley et al. (1992) and Liu (1995a). Collection of exsolved gases for gas isotopic analyses was carried out using inverted glass bottles submerged in sample water at the discharge outlet of the flow chamber. The depositional ages of aquifer sediments corresponding to the depth of each well screen were either determined by ${ }^{14} \mathrm{C}$ dating of biogenic (i.e., plant or shell) fragments from the sediment cores corresponding to well screens, or estimated by correlation of neighboring strata with known ${ }^{14} \mathrm{C}$ ages (Chen and Liu, 2007). The original $\mathrm{CO}_{2}$, if any, in the gas samples was eliminated by bubbling the gas through $0.5 \mathrm{M} \mathrm{BaCl}_{2}$ solution under $\mathrm{pH} 13$ to facilitate carbonate $\left(\mathrm{BaCO}_{3}\right)$ precipitation, and further passing through an 
ascarite column before any hydrocarbon gas was combusted and converted to $\mathrm{CO}_{2}$ for ${ }^{14} \mathrm{C}$ dating and $\delta^{13} \mathrm{C}$ determinations. The ${ }^{14} \mathrm{C}$ activity was measured by the ultra-low level liquid scintillation counter, Quantulus $1220^{\mathrm{TM}}$ (Gupta and Polach, 1985). The maximum determinable radiocarbon age, defined by the two abovebackground conventions described by Stuiver and Polach (1977), is $\sim 50 \mathrm{Ka}$ for our laboratory. The zinc technique (Coleman et al., 1988) was used to convert $\mathrm{H}_{2} \mathrm{O}$ resulting from combustion of a $\mathrm{CH}_{4}$ sample to $\mathrm{H}_{2}$ for $\delta^{2} \mathrm{H}$ analyses. Stable isotope analyses were performed on a triple-collecting mass spectrometer and are expressed in the usual delta notation relative to the PDB $\left(\delta^{13} \mathrm{C}\right)$ and SMOW $\left(\delta^{2} \mathrm{H}\right)$ standards. Analytical reproducibility was better than $0.1 \%$ or $\delta^{13} \mathrm{C}$ and $3 \%$ for $\delta^{2} \mathrm{H}$. The ${ }^{14} \mathrm{C}$ results of DIC and $\mathrm{CH}_{4}$ were reported as conventional ${ }^{14} \mathrm{C}$ ages (Stuiver and Polach, 1977) for comparison with depositional ages of aquifer sediments.

\section{Results and discussion}

The analytical results of $\delta^{13} \mathrm{C}$ and ${ }^{14} \mathrm{C}$ ages for methane and dissolved inorganic carbon are listed in Table 1 . In addition, stratigraphic ${ }^{14} \mathrm{C}$ ages for each screen level are estimated by lateral correlation and average depositional rates based on the age data of Chen and Liu (2007). It is evident that except for sample IL01(IV) from the Ilan plain all other $\delta^{13} \mathrm{C}$ values for $\mathrm{CH}_{4}$ samples fall in the range $-67 \%$ o to $-78 \%$, demonstrating that $\mathrm{CH}_{4}$ was formed via bacteria mediated $\mathrm{CO}_{2}$ reduction (Fig. 3). This is further supported by the $\delta^{2} \mathrm{H}(-211.8 \%)$ and $\delta^{13} \mathrm{C}(-65.31 \%)$ values for meth-

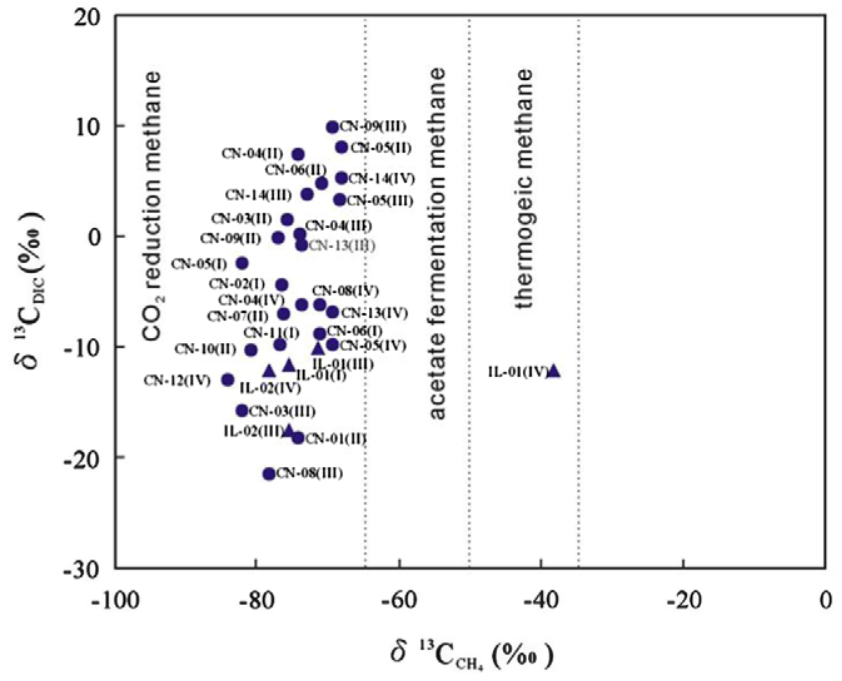

Fig. 3. Plot of $\delta^{13} \mathrm{C}_{\mathrm{DIC}}$ vs. $\delta^{13} \mathrm{C}_{\mathrm{CH}_{4}}$ for groundwater from the Chianan and Ilan plains. The general ranges of $\delta^{13} \mathrm{C}$ values for methane generated by different pathways according to the classification scheme of Barker and Fritz (1981) are also shown.

ane from well CN-03(III) on the classification scheme of Coleman et al. (1995) and the generally positive correlation between the ${ }^{14} \mathrm{C}_{\mathrm{DIC}}$ and ${ }^{14} \mathrm{C}_{\mathrm{CH}_{4}}$ ages (Fig. 4). A general increasing trend of ${ }^{14} \mathrm{C}_{\mathrm{DIC}}$

Table 1

${ }^{14} \mathrm{C}$ ages and $\delta^{13} \mathrm{C}$ values for dissolved methane $\left(\mathrm{CH}_{4}\right)$ and inorganic carbon (DIC), and stratigraphic age of each well in the Chianan and Ilan plains.

\begin{tabular}{|c|c|c|c|c|c|c|c|}
\hline \multirow[t]{2}{*}{ Sample site ${ }^{a}$} & \multirow[t]{2}{*}{ Aquifer } & \multirow[t]{2}{*}{ Well screen depth (m) } & \multicolumn{2}{|l|}{$\mathrm{CH}_{4}$} & \multicolumn{2}{|l|}{ DIC } & \multirow[t]{2}{*}{ Estimated Stratigraphic ${ }^{14} \mathrm{C}$ age $(\mathrm{yBP})$} \\
\hline & & & ${ }^{14} \mathrm{C}$ age (yBP) & $\delta^{13} \mathrm{C}(\% \circ \mathrm{PDB})$ & ${ }^{14} \mathrm{C}$ age (yBP) & $\delta^{13} \mathrm{C}(\% \circ$ PDB $)$ & \\
\hline $\mathrm{CN}-01(24)^{\mathrm{b}}$ & (II) & $62-86$ & $10010 \pm 60$ & -74.3 & $10050 \pm 70$ & -18.2 & $\sim 10000$ \\
\hline $\mathrm{CN}-02$ (27) & (I) & $32-50$ & $6210 \pm 60$ & -76.6 & $5070 \pm 50$ & -4.5 & $\sim 7000-9000$ \\
\hline \multirow[t]{3}{*}{$\mathrm{CN}-03(22)$} & (I) & $32-50$ & $14400 \pm 80$ & -74.3 & $9400 \pm 50$ & -43.5 & $\sim 7000-9000$ \\
\hline & (II) & $104-119$ & $17280 \pm 100$ & -75.8 & $17590 \pm 140$ & 1.4 & $\sim 17000$ \\
\hline & (III) & $150-168$ & $25730 \pm 230$ & -82.2 & $27800 \pm 200$ & -15.7 & S35000 \\
\hline \multirow[t]{3}{*}{$\mathrm{CN}-04(23)$} & (II) & $94-114$ & $13500 \pm 75$ & -74.2 & $13200 \pm 70$ & 7.3 & $\sim 12000$ \\
\hline & (III) & $170-182$ & $13360 \pm 80$ & -74.1 & $13840 \pm 90$ & 0.2 & S40000 \\
\hline & (IV) & $216-228$ & $13520 \pm 80$ & -73.8 & $17300 \pm 100$ & -6.2 & $>40000$ \\
\hline \multirow[t]{4}{*}{$\mathrm{CN}-05$ (14) } & (I) & $18-30$ & $10650 \pm 110$ & -82.2 & $5390 \pm 50$ & -2.5 & $\sim 5100$ \\
\hline & (II) & $114-126$ & $14340 \pm 100$ & -68.1 & $14580 \pm 200$ & 8.0 & $\sim 12000$ \\
\hline & (III) & $172-190$ & $15820 \pm 90$ & -68.3 & $15070 \pm 220$ & 3.3 & S40000 \\
\hline & (IV) & $241-250$ & $12800 \pm 60$ & -69.5 & $18600 \pm 250$ & -9.8 & $>40000$ \\
\hline \multirow[t]{2}{*}{$\mathrm{CN}-06$ (17) } & (I) & $26-44$ & $10370 \pm 60$ & -71.2 & $1410 \pm 40$ & -8.8 & $\sim 7000-9000$ \\
\hline & (II) & $98-110$ & $11310 \pm 70$ & -70.9 & $10300 \pm 150$ & 4.8 & $\sim 12000$ \\
\hline $\mathrm{CN}-07$ (18) & (II) & $101-113$ & $11180 \pm 60$ & -76.3 & $8270 \pm 70$ & -7.0 & $\sim 12000$ \\
\hline \multirow[t]{2}{*}{$\mathrm{CN}-08$ (15) } & (III) & $230-239$ & $30070 \pm 280$ & -78.2 & $22850 \pm 200$ & -21.4 & $>40000$ \\
\hline & (IV) & $265-283$ & $17490 \pm 100$ & -71.2 & n.d. ${ }^{\mathrm{c}}$ & -6.3 & S40000 \\
\hline \multirow[t]{2}{*}{$\mathrm{CN}-09$ (13) } & (II) & $94-106$ & $11820 \pm 70$ & -77.1 & $9600 \pm 70$ & -0.2 & $\sim 12000$ \\
\hline & (III) & $121-133$ & $12620 \pm 70$ & -69.3 & $13500 \pm 140$ & 9.9 & $\sim 13000$ \\
\hline $\mathrm{CN}-10$ (10) & (III) & $191-203$ & $42250 \pm 1100$ & -80.8 & $37900 \pm 700$ & -10.3 & $>40000$ \\
\hline $\mathrm{CN}-11(7)$ & (I) & $18-33$ & $9530 \pm 70$ & -76.9 & $5030 \pm 80$ & -9.9 & $\sim 5100$ \\
\hline $\mathrm{CN}-12$ (4) & (IV) & $215-227$ & $33930 \pm 450$ & -84.2 & $31000 \pm 450$ & -13.0 & $>40000$ \\
\hline \multirow[t]{2}{*}{$\mathrm{CN}-13$ (32) } & (III) & $176-188$ & $19150 \pm 100$ & -73.8 & $18670 \pm 100$ & -0.8 & S40000 \\
\hline & (IV) & $230-248$ & $17720 \pm 120$ & -69.4 & $20150 \pm 150$ & -6.9 & $>40000$ \\
\hline \multirow[t]{2}{*}{$\mathrm{CN}-14$ (1) } & (III) & 180-192 & $16680 \pm 95$ & -72.9 & $18300 \pm 120$ & 3.8 & $>40000$ \\
\hline & (IV) & $233-251$ & $23070 \pm 150$ & -68.1 & $31500 \pm 700$ & 5.2 & $>40000$ \\
\hline \multirow[t]{4}{*}{ IL-01 } & (I) & $13-37$ & $11770 \pm 120$ & -75.6 & $5120 \pm 90$ & -11.6 & $\sim 1000-4000$ \\
\hline & (II) & $60-78$ & n.d. & n.d. & $11700 \pm 70$ & -8.0 & $\sim 6000$ \\
\hline & (III) & $100-118$ & $22000 \pm 850$ & -71.5 & $15350 \pm 110$ & -10.1 & $\sim 8500$ \\
\hline & (IV) & $136-151$ & $35700 \pm 200$ & -38.2 & $21700 \pm 100$ & -12.1 & $\mathrm{~S} 10000$ \\
\hline \multirow[t]{4}{*}{ IL-02 } & (I) & $3-15$ & n.d. & n.d. & $3510 \pm 40$ & -13.0 & n.d. \\
\hline & (II) & $29-41$ & n.d. & n.d. & $14900 \pm 100$ & -9.0 & n.d. \\
\hline & (III) & $64-82$ & $21300 \pm 1050$ & -75.4 & $16900 \pm 80$ & -17.6 & $\sim 6000-8000$ \\
\hline & (IV) & $152-176$ & $23050 \pm 820$ & -78.4 & $19100 \pm 140$ & -12.1 & $\sim 15000-17000$ \\
\hline
\end{tabular}

\footnotetext{
a $\mathrm{CN}$, Chianan plain; IL, Ilan plain.

b Number in the bracket denotes the well number used by Chen and Liu (2007) for the identical well.

c n.d., not determined.
} 


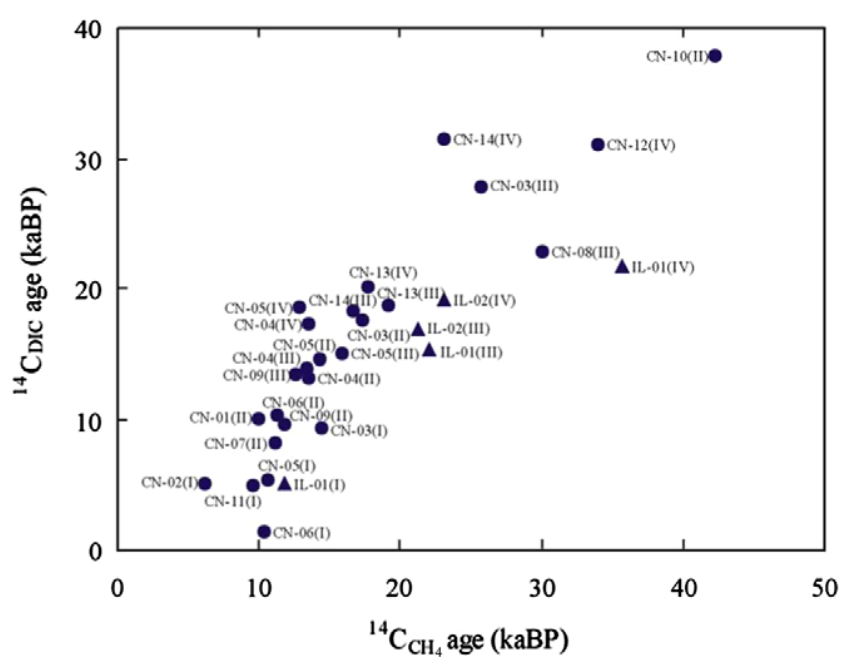

Fig. 4. Plot of ${ }^{14} \mathrm{C}$ ages for dissolved methane $\left(\mathrm{CH}_{4}\right)$ and inorganic carbon (DIC) from the Chinana (CN) and Ilan (IL) plains. (I), (II), (III), (IV): number of aquifers. A positive correlation between the ages of the two components can be found.
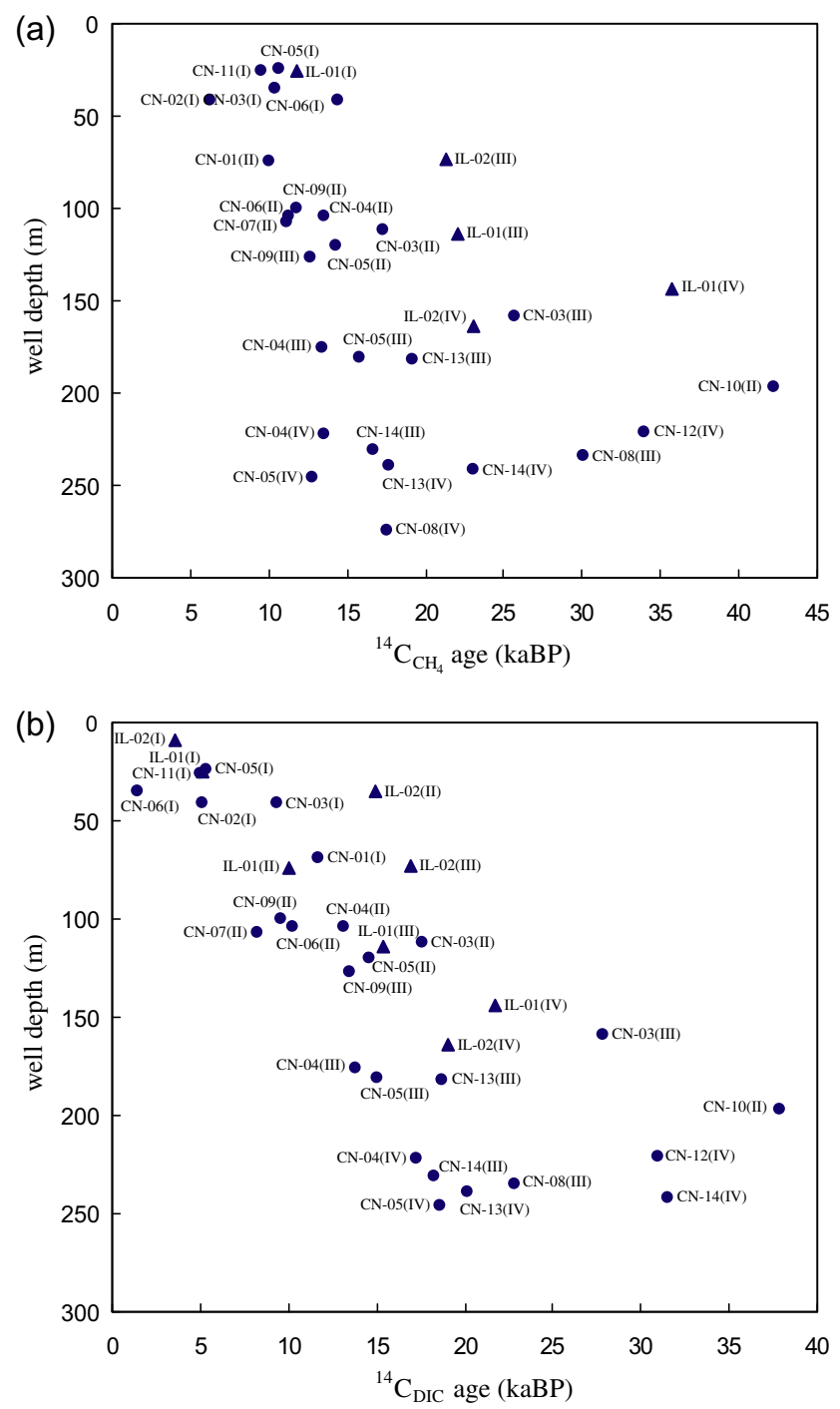

Fig. 5. Plot of well depth vs. ${ }^{14} \mathrm{C}$ age of (a) $\mathrm{CH}_{4}$ and (b) DIC from the Chianan (CN) and Ilan (IL) plains. A generally positive correlation can be found. and ${ }^{14} \mathrm{C}_{\mathrm{CH}_{4}}$ ages with well depths can also be found (Fig. 5). In addition to the characteristics mentioned above, we make the following relevant comments.

\subsection{Chianan plain}

It is worth pointing out that $\delta^{13} \mathrm{C}_{\mathrm{DIC}}$ values for about 18 of the 25 water samples from the Chianan plain are considerably greater than $0 \%$ (up to 9.9\%o), suggesting the occurrence of Rayleigh enrichment during $\mathrm{CO}_{2}$ reduction as was invoked by Nissenbaum et al. (1972) to explain unusually heavy $\delta^{13} \mathrm{C}$ values of interstitial water $\mathrm{CO}_{2}$. According to the Rayleigh model, successive fractions of $\mathrm{CO}_{2}$ are reduced to produce ${ }^{12} \mathrm{C}$-enriched $\mathrm{CH}_{4}$, leaving residual $\mathrm{CO}_{2}{ }^{13} \mathrm{C}$-enriched. Similar enrichment in $\delta^{13} \mathrm{C}$ (as high as $+35 \%$ ) was reported for DIC in groundwater with dissolved methane in the United States (Scott et al., 1994; Aravena et al., 2003) and Australia (Smith and Pallasser, 1996). In contrast, the very negative value for DIC $(-43.5 \%$ ) in $\mathrm{CN}-03$ (I) suggests that methane oxidation occurred.

Comparisons of ${ }^{14} \mathrm{C}$ ages between $\mathrm{CH}_{4}$ and DIC, and between DIC and sediment deposition for each well are shown in Table 2 . In view of the probability of water mixing during pumping, wide span of well screen, and the uncertainty of depositional ages, ${ }^{14} \mathrm{C}$ ages of $\mathrm{CH}_{4}$, DIC, and strata are arbitrarily defined as significantly different if their difference is greater than 10 times that of the larger

Table 2

Comparison of ${ }^{14} \mathrm{C}$ ages between coexisting dissolved methane $\left(\mathrm{CH}_{4}\right)$ and inorganic carbon (DIC), and between DIC and strata from each individual well.

\begin{tabular}{|c|c|c|c|c|c|c|}
\hline \multirow[t]{2}{*}{ Aquifer } & \multirow[t]{2}{*}{ Sample site ${ }^{a}$} & \multicolumn{5}{|c|}{${ }^{14} \mathrm{C}$ age ${ }^{\mathrm{b}}$} \\
\hline & & $\mathrm{CH}_{4}$ & & DIC & & Strata \\
\hline \multirow[t]{5}{*}{ (I) } & $\mathrm{CN}-02$ & & $>$ & & $=$ & \\
\hline & $\mathrm{CN}-03$ & & $>$ & & $=$ & \\
\hline & $\mathrm{CN}-05$ & & $>$ & & $=$ & \\
\hline & $\mathrm{CN}-06$ & & $>$ & & $=$ & \\
\hline & $\mathrm{CN}-11$ & & $>$ & & $=$ & \\
\hline \multirow[t]{7}{*}{ (II) } & $\mathrm{CN}-01$ & & $=$ & & $=$ & \\
\hline & $\mathrm{CN}-03$ & & $=$ & & $=$ & \\
\hline & $\mathrm{CN}-04$ & & $=$ & & $=$ & \\
\hline & $\mathrm{CN}-05$ & & $=$ & & $=$ & \\
\hline & $\mathrm{CN}-06$ & & $=$ & & $=$ & \\
\hline & $\mathrm{CN}-07$ & & $>$ & & $<$ & \\
\hline & $\mathrm{CN}-09$ & & $>$ & & $<$ & \\
\hline \multirow[t]{8}{*}{ (III) } & $\mathrm{CN}-03$ & & $=$ & & $<$ & \\
\hline & $\mathrm{CN}-04$ & & $=$ & & $<$ & \\
\hline & $\mathrm{CN}-05$ & & $=$ & & $<$ & \\
\hline & $\mathrm{CN}-08$ & & $>$ & & $<$ & \\
\hline & CN-09 & & $=$ & & $=$ & \\
\hline & $\mathrm{CN}-10$ & & $=$ & & $<$ & \\
\hline & $\mathrm{CN}-13$ & & $=$ & & $<$ & \\
\hline & $\mathrm{CN}-14$ & & $=$ & & $<$ & \\
\hline \multirow[t]{5}{*}{ (IV) } & $\mathrm{CN}-04$ & & $<$ & & $<$ & \\
\hline & $\mathrm{CN}-05$ & & $<$ & & $<$ & \\
\hline & $\mathrm{CN}-12$ & & $=$ & & $<$ & \\
\hline & $\mathrm{CN}-13$ & & $<$ & & $<$ & \\
\hline & $\mathrm{CN}-14$ & & $<$ & & $<$ & \\
\hline (I) & IL-01 & & $>$ & & $>$ & \\
\hline (II) & IL-01 & & $(\text { n.d. })^{c}$ & & $>$ & \\
\hline \multirow[t]{2}{*}{ (III) } & IL-01 & & $>$ & & $>$ & \\
\hline & IL-02 & & $>$ & & $>$ & \\
\hline \multirow[t]{2}{*}{ (IV) } & IL-01 & & $>$ & & $>$ & \\
\hline & IL-02 & & $>$ & & $>$ & \\
\hline
\end{tabular}

\footnotetext{
${ }^{a} \mathrm{CN}$, Chianan plain; IL, Ilan plain.

b Two ages are defined as equal if their difference is less than 10 times of the larger standard error $(\sigma)$ of the two ages. Otherwise, the greater $(>)$ or less $(<)$ symbol is used.
}

c n.d., not determined. 
standard deviation of two ages. Otherwise, two ages are considered to be essentially equal. Accordingly, it is evident that the ${ }^{14} \mathrm{C}$ age of DIC is essentially the same as that of aquifer sediments from each individual shallow well of aquifer (I) ( $<60 \mathrm{~m}$ depth) in the Chianan plain. By contrast, the ${ }^{14} \mathrm{C}$ ages of $\mathrm{CH}_{4}$ from all aquifer (I) wells are significantly greater than those of coexisting DIC, which in turn are essentially coeval with coexisting sediments except $\mathrm{CN}-02(\mathrm{I})$ and $\mathrm{CN}-06$ (I), indicating the presence of $\mathrm{CH}_{4}$ from the underlying aquifers. It is interesting to note that seeps of older methane from underlying sediments are commonly found in some other coastal waters and shallow aquifers (e.g. Laier et al., 1996; Laier, 2003). The relatively shallow and up-gradient $\mathrm{CN}-02$ (I) and $\mathrm{CN}-06$ (I) have remarkably younger ${ }^{14} \mathrm{C}_{\text {DIC }}$ ages than their respective sediment depositional ages, very probably due to mixing of younger $\mathrm{CO}_{2}$ from overlying layers.

Although $\mathrm{CH}_{4}$ ages for samples CN-07(II) and CN-09(II) are slightly older than their respective DIC ages, all the other ${ }^{14} \mathrm{C}$ ages of $\mathrm{CH}_{4}$, DIC and aquifer sediments for individual wells in aquifer (II) are essentially equal. This demonstrates that dissolved methane and DIC of aquifer (II) were formed in-situ via bacterial degradation of sedimentary organic matter within the aquifer and implies that the groundwater flow rate is very slow.

Like aquifer (II), all the ${ }^{14} \mathrm{C}$ ages of $\mathrm{CH}_{4}$ from aquifer (III) (except sample $\mathrm{CN}-08$ ) are also essentially the same as those of their coexisting DIC. In contrast to aquifer (II), however, both $\mathrm{CH}_{4}$ and DIC from each individual well of aquifer (III) (except $\mathrm{CN}-09$ ) and aquifer (IV) are remarkably younger than their respective sediment depositional ages. Obviously, current groundwaters in aquifer (III) and (IV) were recharged much later than the deposition of their sediments. Note that the sediments of aquifers (III) and (IV) were deposited during the interval between 20 and $90 \mathrm{KaBP}$ (Liu et al., 1997; Chen, 2008) when the eustatic sea-level was much lower than present and hydraulic gradients were much larger causing faster discharge of groundwater. The $\mathrm{CH}_{4}$ from $\mathrm{CN}-08$ (III) is significantly older than its coexisting DIC and the $\mathrm{CH}_{4}$ from the underlying CN-08 (IV). Hackley et al (1992) also noted that $\mathrm{CH}_{4}$ in their study is generally older than DIC. They interpreted this as resulting from the fact that $\mathrm{CO}_{2}$ from degradation of sedimentary organic matter can react to form $\mathrm{CH}_{4}$ before equilibration with DIC. We believe the same effect might have occurred in CN-08(III).

Except for sample $\mathrm{CN}-12$ (IV), the ${ }^{14} \mathrm{C}$ ages for DIC samples from $\mathrm{CN}-04,-05,-13$, and -14 wells tapping the deepest aquifer (IV) are significantly older than those of their respective $\mathrm{CH}_{4}$ (Fig. 4), probably due to dissolution of carbonate sediments. Moreover, $\mathrm{CH}_{4}$ samples from $\mathrm{CN}-05$ (IV) and 08(IV) are much younger than those from their respective overlying wells in aquifer (III), suggesting that some portions of aquifer (IV) have faster groundwater discharge than their overlying aquifer (III).

\subsection{Ilan plain}

The $\mathrm{CH}_{4}$ of IL-01(IV) has a much older ${ }^{14} \mathrm{C}$ age than its coexisting DIC. In addition, it is of thermogenic origin as is shown by the $\delta^{13} \mathrm{C}_{\mathrm{CH}_{4}}$ of $-38.2 \%$, very probably reflecting the thermocatalytic effect of shallow and young intrusive igneous rocks under the plain (Liu, 1995b; Yang et al., 2005). This interpretation is further supported by the much higher $\mathrm{CO}_{2}$ content of $\sim 16 \mathrm{vol} \%$, as compared with $<1 \mathrm{vol} \%$ in other wells, although no higher hydrocarbon (e.g. ethane) was found. It is worth pointing out that the well screen of IL-01(IV) is close to the underlying metamorphic basement. Besides, weak-alkaline carbonic acid springs, often with $\mathrm{CO}_{2}$ gas bubbles, are common in and around the near-by metamorphic mountain range.

Except for IL-01(IV), all $\mathrm{CH}_{4}$ samples from the Ilan plain have $\delta^{13} \mathrm{C}$ values in the range of $-71 \%$ o to $-78 \%$, suggesting that they originated from $\mathrm{CO}_{2}$ reduction via microbial decomposition. These microbial $\mathrm{CH}_{4}$ gases also have much older ${ }^{14} \mathrm{C}$ ages than their accompanying DIC, indicating a mixture of older $\mathrm{CH}_{4}$ from the underlying strata. Moreover, both $\mathrm{CH}_{4}$ and DIC of each well are distinctly older than the depositional age of sediments at depths corresponding to each individual well screen. The most likely cause for the occurrence of much older $\mathrm{CH}_{4}$ and DIC is that the $\mathrm{CH}_{4}$ and DIC in these aquifers is mixing by $\mathrm{CO}_{2}$ and $\mathrm{CH}_{4}$ from the underlying strata.

\section{Conclusions}

The stable carbon isotope ratios $\left(\delta^{13} \mathrm{C}\right)$ and ${ }^{14} \mathrm{C}$ ages for dissolved methane and inorganic carbon from a total of 34 groundwater samples, in addition to depositional ages of sediments, at 16 sites in the Chianan and Ilan plain of Taiwan were measured. The results show that, except for one thermogenic $\mathrm{CH}_{4}$ sample from the Ilan plain, all other $\mathrm{CH}_{4}$ samples were produced via microbially mediated $\mathrm{CO}_{2}$ reduction. Most $\delta^{13} \mathrm{C}_{\mathrm{DIC}}$ values are considerably greater than $-10 \%$ and even up to $10 \%$ due to Rayleigh enrichment during $\mathrm{CO}_{2}$ reduction. Almost all the ${ }^{14} \mathrm{C}$ ages of $\mathrm{CH}_{4}$ samples from the shallow aquifer (I) ( $<60 \mathrm{~m}$ depth) of the Chianan plain are greater than the ${ }^{14} \mathrm{C}$ ages of coexisting DIC and sediment deposition, suggesting the presence of $\mathrm{CH}_{4}$ that has migrated from the underlying aquifers. In contrast, ${ }^{14} \mathrm{C}$ ages of coexisting $\mathrm{CH}_{4}$, DIC, and deposition of sediments for aquifer (II) in the Chianan plain are essentially equal, reflecting in-situ generation of $\mathrm{CH}_{4}$ and DIC and sluggishness of the groundwater flow. Moreover, both $\mathrm{CH}_{4}$ and DIC from each individual well of aquifers (III) and (IV) in the Chianan plain are remarkably younger than the respective depositional ages of these aquifers. Obviously, these groundwaters recharged much later than the deposition of aquifer sediments. However, the age of methane depends on the age of the organic matter source as well as groundwater flow. Finally, the $\mathrm{CH}_{4}$ of each well in the Ilan plain is distinctly older than coexisting DIC, which in turn is much older than the depositional age of aquifer sediments, demonstrating dissolution of much older $\mathrm{CO}_{2}$ and $\mathrm{CH}_{4}$ from underlying strata.

\section{Acknowledgements}

The authors thank Drs. B.M. Jahn, T. Laier and an anonymous reviewer for valuable comments and suggestions. We are grateful to Dr. Chao-Li Liu for technical instructions and measuring stable hydrogen isotopes. Thanks are also due to the Central Geological Survey, Ministry of Economic Affairs (ROC) for providing sediment core samples and related geological information, and the Groundwater Exploitation and Conservation Center of Taiwan Sugar Company for helping in water sampling. We also wish to thank Su-Chin Kang and Chun-Yen Chou for their laboratory assistance. This study is supported financially by National Science Council, Republic of China (Grant: NSC95-2116-M-002-017-MY3).

\section{References}

Aravena, R., Wassenaar, L.I., Barker, J.F., 1995. Distributuion and isotopic characterization of methane in a confined aquifer in southern Ontario, Canada. Journal of Hydrology 173, 51-70.

Aravena, R., Harrison, S.M., Barker, J.F., Abercrombie, H., Rudolph, D., 2003. Origin of methane in the Elk Valley coalfield, southeastern British Columbia, Canada. Chemical Geology 195, 219-227.

Barker, J.F., Fritz, P., 1981. The occurrence and origin of methane in some groundwater flow systems. Canadian Journal of Earth Science 18, 1802-1816.

Chen, K.Y., Liu, T.K., 2007. Major factors controlling arsenic occurrence in the groundwater and sediments of the Chianan coastal plain, SW Taiwan. Terrestrial, Atmospheric and Oceanic Sciences 18, 975-994.

Chen, Y.W., 2008. Luminescence dating on Quaternary sediments: cases of active structures in western Taiwan. Ph.D. Thesis, Institute of Geosciences, National Taiwan University, 115p. 
Coleman, D.D., Liu, C.L., Riley, K.M., 1988. Microbial methane in the shallow Paleozoic sediments and glacial deposits of Illinois. Chemical Geology 71, 23-40.

Coleman, D.D., Liu, C.L., Hackley, K.C., Pelphrey, S.D., 1995. Isotopic identification of landfill methane. Environmental Geosciences 2, 95-103.

Gooddy, D.C., Darling, W.G., 2005. The potential for methane emissions from groundwaters of the UK. Science of the Total Environment 339, 117-126.

Gupta, S.K., Polach, H.A., 1985. Radiocarbon Dating Practices at ANU. Radiocarbon Laboratory, Research School of Pacific Studies, Australian National University, Canberra, 176p.

Hackley, K.C., Liu, C.L., Coleman, D.D., 1992. ${ }^{14} \mathrm{C}$ dating of groundwater containing microbial $\mathrm{CH}_{4}$. In: Long, A., Kra, R.S. (Eds.), Proceedings of 14 th International ${ }^{14} \mathrm{C}$ Conference, Radiocarbon, vol. 34, pp. 686-695.

Ho, C.S., 1975. An Introduction to the Geology of Taiwan: Explanatory Text of the Geologic Map of Taiwan. Ministry of Economic Affairs, Taipei, Taiwan. 153p.

Hsu, L.M., 1984. Pleistocene formation with dissolved-in-water type gas in the Chianan plain, Taiwan. Petroleum Geology of Taiwan 20, 199-213.

Lansdown, J.M., Quay, P.D., King, S.L., 1992. $\mathrm{CH}_{4}$ production via $\mathrm{CO}_{2}$ reduction in a temperate bog: a source of ${ }^{13} \mathrm{C}$-depleted $\mathrm{CH}_{4}$. Geochimica et Cosmochimica Acta $56,3493-3503$.

Laier, T., 2003. Migration patter of methane related to glacio-tectonic deformation of marine deposits in the Kattegat-Skagerrak area. In: Proceedings of the 7th International Conference on Gas Geochemistry, pp. 44-46.

Laier, T., Kuijpers, A., Denneggard, B., Heier-Nielsen, S., 1996. Origin of shallow gas in Skagerrak and Kattegat - evidence from stable isotopic analyses and radiocarbon dating. Bulletin of Geology Survey of Norway 430, 129-136.

Liu, T.K., 1995a. Estimating flow and recharge rates of groundwater in western Taiwan using radiocarbon and tritium. Radiocarbon 37, 531-542.

Liu, C.C., 1995b. The Ilan plain and the southwestward extending Okinawa Trough. Journal of Geological Society of China 38, 229-242.

Liu, T.K., Sung, Q.C., Chen, K.Y., Pi, Z.L., Yang, C.H., Cheng, P.H., 1997. Tectonic subsidence and uplift in the Zaikang-Hopi area of south-western Taiwan since the Late Pleistocene. Journal of Geological Society of China 40, 155-165.

Lu, F.J., 1990. Fluorescent humic substances and blackfoot disease in Taiwan. Applied Organometallic Chemistry 4, 191-195.

Nissenbaum, A., Presley, B.J., Kaplan, I.R., 1972. Early diagenesis in a reducing fjord, Saanich Inlet, British Columbia, I. Chemical and isotopic changes in major components of interstitial water. Geochimica et Cosmochimica Acta 36, 10071027.
Oremland, R.S., Marsh, L.M., Polcin, S., 1982. Mathane production and simultaneous sulfate reduction in anoxic salt marsh sediment. Nature 296, 143-145.

Oremland, R.S., 1988. Biogeochemistry of methanogenic bacteria. In: Zehnder, A.J.B. (Ed.), Biology of Anaerobic Microorganism. Wiley Interscience, pp. 641-706.

Schoell, M., 1980. The hydrogen and carbon isotopic compositions of methane from natural gases of various origins. Geochimica et Cosmochimica Acta 44, 649661.

Schoell, M., 1988. Multiple origins of methane in the earth. Chemica Geology 71, $1-10$.

Scott, A.R., Kaiser, W.R., Ayers Jr., W.B., 1994. Thermogenic and secondary biogenic gases, San Juan basin, Colorado and New Mexico - implications for coalbed gas producibility. American Association of Petroleum Geologists Bulletin 78, 11861209.

Smedley, P.L., Kinniburgh, D.G., 2002. A review of the source, behavior and distribution of arsenic in natural waters. Applied Geochemistry 17, 517-568.

Smith, J.W., Pallasser, R.J., 1996. Microbial origin of Australian coalbed methane. American Association of Petroleum Geologists Bulletin 80, 891-897.

Stuiver, M., Polach, H.A., 1977. Discussion: Reporting of ${ }^{14} \mathrm{C}$ data. Radiocarbon 19 355-363.

Stumm, W., Morgan, J.J., 1996. Aquatic Chemistry, third ed. Wiley-Interscience, $1022 p$.

Tseng, W.P., Chen, W.Y., Sung, J.L., Chen, J.S., 1961. A clinical study of Blackfoot disease in Taiwan, an endemic peripheral vascular disease. Memoir of College of Medicine, National Taiwan University 7, 1-18.

Tyler, S.C., 1991. The global methane budget. In: Rodgers, J.E., Whitman, W.B. (Eds.), Microbial Production and Consumption of Greenhouse Gases: Methane, Nitrogen oxides, and Halomethanes. American Society of Microbiology, Washington DC, pp. 7-38.

Whiticar, M.J., Faber, E., Schoell, M., 1986. Biogenic methane formation in marine and freshwater environments: $\mathrm{CO}_{2}$ reduction vs. acetate fermentation - isotope evidence. Geochimica et Cosmochimica Acta 50, 693-709.

Whiticar, M.J., 1999. Carbon and hydrogen isotope systematics of bacterial formation and oxidation of methane. Chemical Geology 161, 291-314.

Yang, T.Y., Lan, T.F., Lee, H.F., Fu, C.C., Chuang, P.C., Lo, C.H., Chen, C.H., Chen, C.T., Lee, C.S., 2005. Gas compositions and helium isotopic ratios of fluid samples around Kueishantao, NE offshore Taiwan and its tectonic implications. Geochemical Journal 39, 469-480. 